\title{
Cropping systems on root rot and soybean seed yield
}

\section{Maira Maier ${ }^{1}$ Clovis Arruda Souza ${ }^{2 *} \odot$ Ricardo Trezzi Casa $^{2}$}

\footnotetext{
${ }^{1}$ Doutorado em Produção Vegetal, Universidade do Estado de Santa Catarina (UDESC), Lages, SC, Brasil.

${ }^{2}$ Departamento de Agronomia, Universidade do Estado de Santa Catarina (UDESC), 88.520-000, Lages, SC, Brasil. E-mail: clovis.souza@udesc.br. ${ }^{*}$ Corresponding author.
}

\begin{abstract}
Root rot (RR), which can occur in different cropping systems, affects soybean seed yield. The aim of this study was to determine the incidence of RR in soybean crop systems and its relationship with soybean yield. The study was carried out for two growing seasons in a no-till system consisting of four soybean crop systems: soybean-oat + soybean-oat, soybean-maize + soybean-maize, soybean-wheat + soybeanwheat and soybean-pasture+soybean-pasture. Data were submitted to Pearson's correlation. Incidence of RR, mainly charcoal rot and sudden death, was more than $50 \%$ in soybean roots for all the soybean crop systems and consequently decreased yield by around $22 \mathrm{~kg}$ ha ${ }^{-1}$ of seed for every $1 \%$ increase in RR. Root rot led to a decline in seed yield from 20 to $102 \mathrm{~kg} \mathrm{ha}^{-1}$ in the first season and 9 to $32 \mathrm{~kg} \mathrm{ha}{ }^{-1}$ in the second season, considering all the cropping systems. Soybean + pasture was the lowest productive system, with a negative RR impact of 74.9 and $32.9 \mathrm{~kg}$ ha-1 in the first and second season, respectively.
\end{abstract}

Key words: Glycine max, root diseases, yield, root healty, Macrophomina, Fusarium.

Sistemas de cultivo afetam podridões radiculares e produtividade de semente de soja

RESUMO: As podridões radiculares podem ocorrer em diferentes sistemas de cultivos e afetar a produtividade. Objetivou-se neste trabalho quantificar a incidência de podridões radiculares em distintos sistemas de sucessão de cultivos e sua relação com a produtividade de sementes soja. A pesquisa foi realizada por duas safras agrícolas, na Região de Ponte Serrada, Santa Catarina, em lavouras de sementes de soja cultivadas em plantio direto que foi subdividida em quatro sistemas de sucessão de cultivos: aveia-soja+aveia-soja, milho-soja+milho-soja, trigo-soja+trigo-soja e pasto-soja+pasto-soja. Os dados foram submetidos à correlação de Pearson e ao teste de médias de Duncan ou F $(P<0,05)$. Constatou-se que a incidência de podridões radiculares, principalmente podridão cinzenta e morte súbita, na média dos sistemas, está acima de $50 \%$ e como consequência gerou redução de produtividade na ordem de $22 \mathrm{~kg} \mathrm{ha}^{-1}$ de semente de soja para cada $1 \%$ de aumento na incidência destas doenças. As podridões radiculares reduzem a produtividade de 20 a $102 \mathrm{~kg} \mathrm{ha}^{-1}$ na primeira safra e, de 9 a $32 \mathrm{~kg}^{-1}$ na segunda safra, considerando todos os sistemas de cultivo. O sistema soja +pasto, é o menos produtivo com impacto negativo das PR de 74,9 e $32,9 \mathrm{~kg} \mathrm{ha}^{-1}$ na primeira e segunda safra, respectivamente.

Palavras-chave: Glycine max, doenças radiculares, desempenho agronômico, Macrophomina, Fusarium.

\section{INTRODUCTION}

Soybean is the most widely grown oil seed in the world, covering 150 million hectares and accounting for production of 345 million metric tons $(\mathrm{t})$. This economically important grain, used for human consumption, oil production, animal feed and fuel, is Brazil's most exported agricultural product (CONAB, 2017a).

In the 2016/2017 growing season, the soybean cultivated area was approximately 34 of million hectares, producing 114 million $\mathrm{t}$ with grain yield of $3364 \mathrm{~kg} \mathrm{ha}^{-1}$ (CONAB, 2017b) and requiring around 2.1 million $\mathrm{t}$ of seeds (CONAB, 2017b; ABRASEM, 2018). In order to increase yield, continuous investment in modern soil management technologies, liming, fertilization, and seeding, associated with efficient weed, pest and disease control is needed (THOMAS \& COSTA, 2010; FREITAS, 2011), in addition to suitable crop rotation. Expansion of soybean growing area has prompted an increase in monoculture farming (PEREZ-BRANDAN et al., 2014); thereby, raising the occurrence and intensity of diseases. All parts of the soybean plant are susceptible to plant pathogens (HARTMAN et al., 1999), especially fungus-related diseases associated with root rot (RR) (HENNING, 2009).

Root rot fungi are natural soil inhabitants that survive on soybean crop remnants on the soil surface, particularly in a no-till system (PEREZ- 
BRANDAN et al., 2014; KLINGELFUSS et al., 2007). Root rot and early plant death (COSTAMILAN, 1999; SARR et al., 2014) affect pod filling, resulting in small, green or deteriorated seeds that compromise seed lot quality and reduce crop yield (SHADAKSHARI et al., 2014). Among the main fungal species are Macrophomina phaseolina (Tassi) Giodanish and Fusarium solani (Mart.) Sacc.

M. phaseolina are found in large numbers on plant hosts such as soybean, common beans, peanuts, cotton, sunflower, castor beans and maize (GUPTA et al., 2012; SARR et al., 2014). Tissue infection and colonization may occur in young plants; although symptoms such as charcoal or grey soybean root or stem rot are more visible in the reproductive phase. Plants grown in compacted soils, periods with no rainfall, nutritional imbalance and high temperatures are more susceptible to the disease (GUPTA et al., 2012; SARR et al., 2014). Managing RR requires preventive measures such as crop rotation, use of less vulnerable cultivars, seeding planning (to minimize plant exposure to periods of drought), maintaining soil moisture (to avoid water stress), avoiding excessive plant density in soybean crop (GUPTA et al., 2012; SARR et al., 2014).

For $F$. solani fungus the symptoms are named sudden death syndrome (SDS), which are influenced by the environment, seeding time, soil homogeneity, temperature and moisture content, air temperature and amount of inoculum in the soil (KLINGELFUSS et al., 2007).

In Brazil, there is scarce information on occurrence of RR in seed production systems or chemical control of RR applying fungicides. Soil decompaction, scarification and subsoiling improve root development conditions; thereby, decreasing the susceptibility of plants to RR, and crop rotation contributes to hampering the survival of these RR fungi (HENNING, 2009).

The aim of this study was to assess management methods (crop systems), RR incidence and prevalence of Macrophomina and Fusarium at early (R2) and late (R8) stages of soybean development for two consecutive growing seasons, in addition to the determining the correlation between seed yield and management methods.

\section{MATERIALS AND METHODS}

The study was conducted in Ponte Serrada, Santa Catarina during the 2014/2015 and 2015/2016 growing seasons, with average temperatures of 22.9 and $21.9^{\circ} \mathrm{C}$, respectively; with total rainfall of 1289 and $1594 \mathrm{~mm}$ in first e second season, respectively (Figure 1) (INMET, 2016). Soil in the experimental area is classified as predominantly typical nitisol (red-yellow podzolic with clay texture); the $0-20 \mathrm{~cm}$ layer contained an average of $322 \mathrm{~g} \mathrm{~kg}^{-1}$ of clay; $35 \mathrm{~g}$ $\mathrm{kg}^{-1}$ of organic matter; water $\mathrm{pH}$ of $5.2 ; 10 \mathrm{mg} \mathrm{dm}^{-3}$ of P; $142.4 \mathrm{mg} \mathrm{dm}^{-3}$ of exchangeable $\mathrm{K}$ (Mehlich 1 extractant); $8.3 \mathrm{cmolc} \mathrm{dm}^{-3}$ of exchangeable $\mathrm{Ca}$ and $3.4 \mathrm{cmolc} \mathrm{dm}^{-3}$ of exchangeable $\mathrm{Mg}\left(\mathrm{KCl} 1 \mathrm{~mol} \mathrm{~L}^{-1}\right.$ of extractor). Soybean seeding of cultivar NS4823 was performed every year in the second half of October for a population of 22 plants $\mathrm{m}^{-2}$. Fertilization and crop treatments were applied in each growing season to achieve soybean seed yield potential of $5 \mathrm{t} \mathrm{ha}^{-1} \mathrm{using}$ soybean growing recommendations, in a similar manner described by SOUZA et al. (2013).

Cropping systems follow a seeding sequence in the same area: i) soybean+oat (oat + soybean + oat + soybean) identified by the following geodesic coordinates: latitude $26^{\circ} 52^{\prime} \mathrm{S}$; longitude $52^{\circ} 01^{\prime} \mathrm{W}$; altitude $995 \mathrm{~m}$; ii) soybean+maize ( maize + fallow + soybean + fallow + maize + fallo w+soybean) (26 51 ' S; 52 $\left.02^{\prime} \mathrm{W} ; 1071 \mathrm{~m}\right)$, iii) soybean+wheat (wheat+soybean+wheat + soybean) (26⒋' S; 52 $01^{\prime}$ 'W; 846m) and iv) soybean+pasture (pasture+soybean+pasture+soybean) $\quad\left(26^{\circ} 56^{\prime} \mathrm{S}\right.$; $\left.52^{\circ} 02^{\prime} \mathrm{W} ; 1057 \mathrm{~m}\right)$; the winter pasture of this cropping system consists of a mixed black oat with ryegrass. Four treatments were established for each cropping system: T1 - plants with no early symptoms of root rot - RR; T2 - plants with early symptoms of RR, consisting of smaller shoots and visible inner tissue discoloring (observed with the help of a penknife) in the hypocotyl region (Macrophomina, charcoal or grey rot and Fusarium by the pinkish color); T3 plants with no late symptoms of RR; and T4 - plants with late symptoms of RR. Early RR symptoms were assessed and characterized in plants at reproductive stage R2 (full bloom) and the late symptoms of RR in stage R8 plants (crop maturity). All treatments were geodetically demarcated using a GPS device (GPS Map Garmin) on 1/18/2015 for the 2014/2015 crop and the same coordinates were used for the 2015/2016 growing season. Geo referencing was necessary to assess each treatment at two growth stages and two growing seasons. Each treatment was identified and predefined as a crop area of more than $100 \mathrm{~m}^{2}$ and 50 meters apart. The experimental units within each treatment consisted of 5 rows measuring $5 \mathrm{~m}$ long.

When plants reached stage R8 (crop maturity, complete defoliation and all pods with yellowstraw coloration), they were evaluated for RR incidence, as follows: plants with no visible symptoms of RR were 


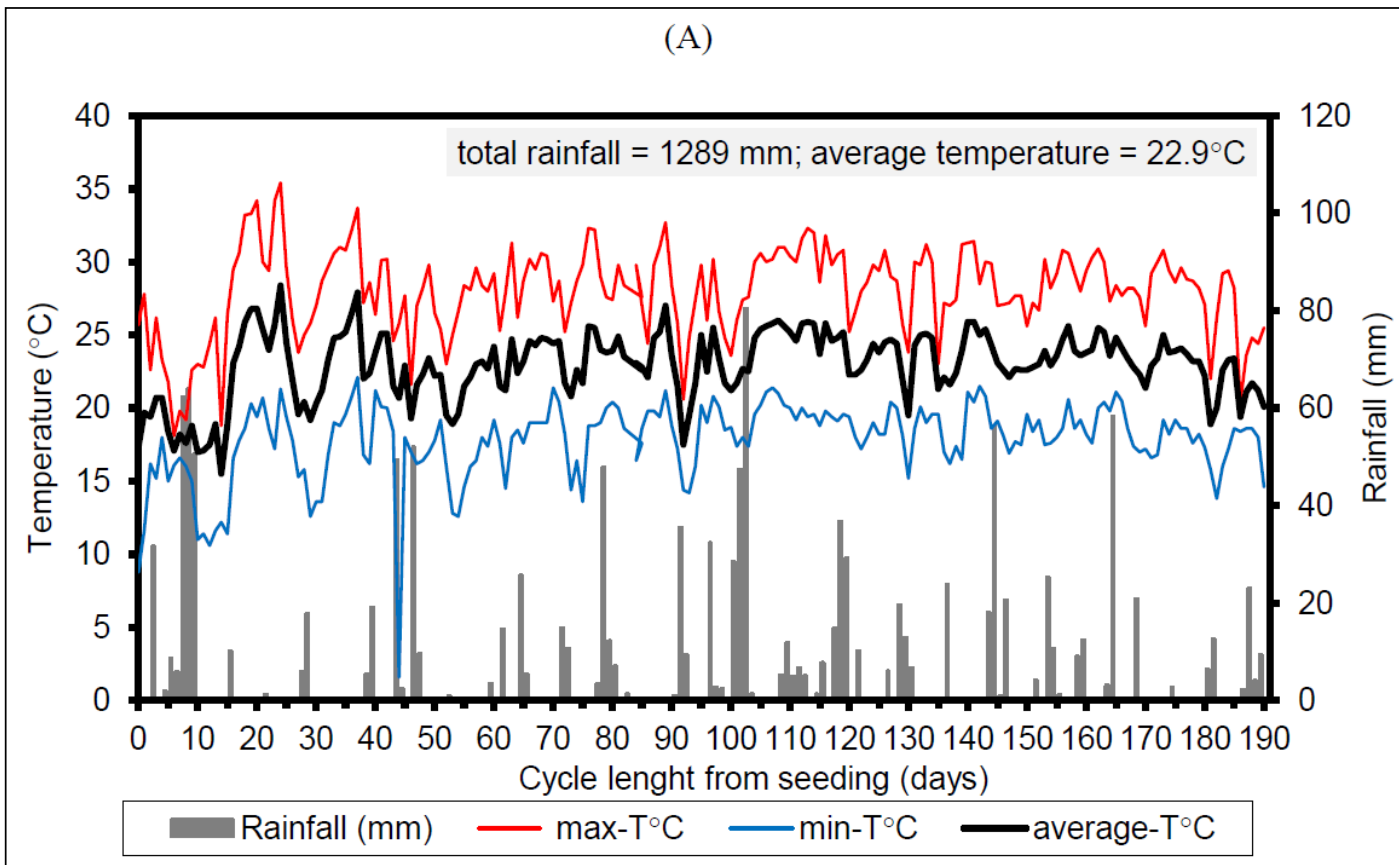

(B)

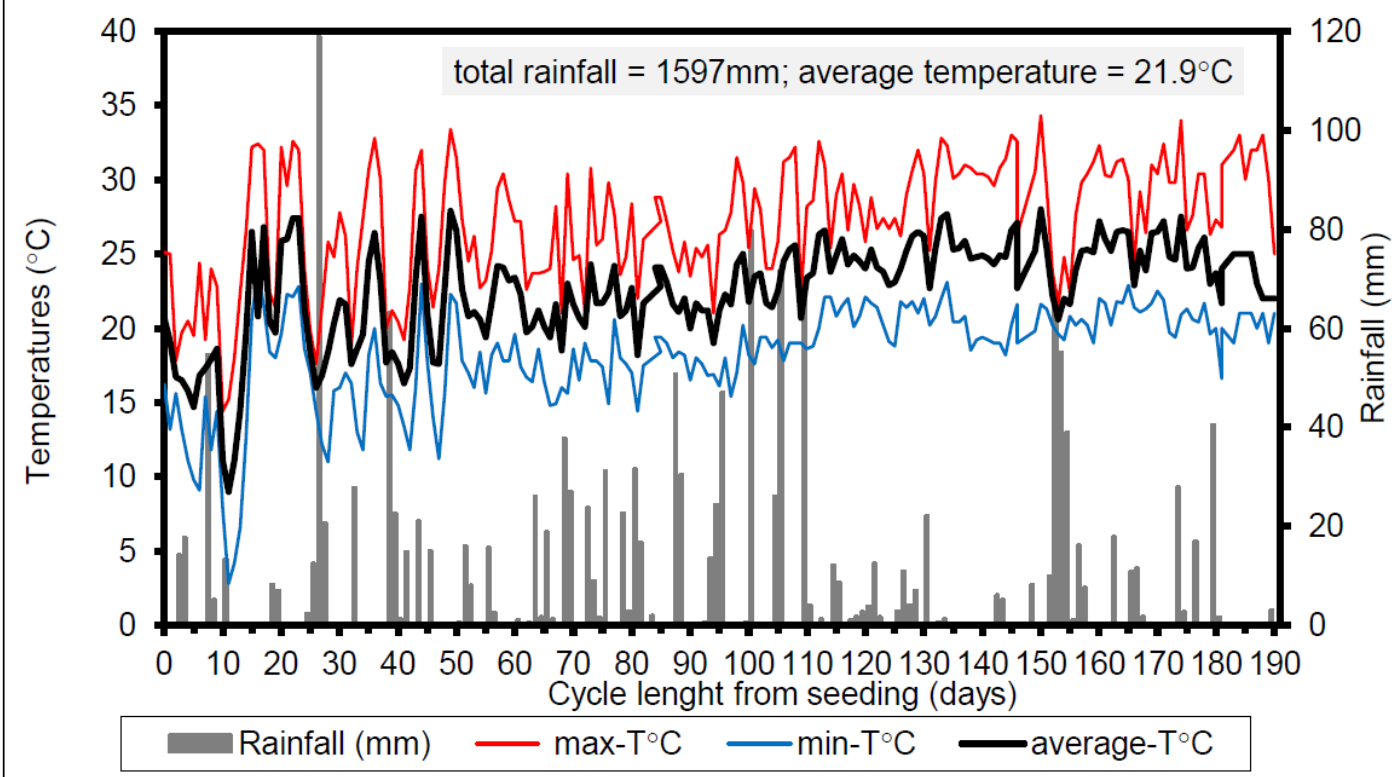

Figure 1 - Rainfall, maximum, average and minimum temperatures during the soybean growing cycle in the 2014/2015 (A) and 2015/2016 (B) growing seasons in Ponte Serrada, SC.

separated from their symptomatic counterparts (only for Macrophomina or Fusarium). This assessment was made in all the plants collected along 5-meter-long rows, totaling five repetitions per treatment.

The RR incidence was obtained by dividing the number of plants with RR by the number of plants sampled and multiplying the result by 100 . Predominance was obtained by dividing the number of plants with Macrophomina by the number of plants with RR and multiplying the value obtained by 100 , and dividing the number of plants with Fusarium by the number of plants with RR and multiplying the result by 100 . 
Yield was obtained by manually harvesting of all the plants in the 5-meter rows of each repetition and each treatment. Next, manual threshing was performed and seed yield was estimated in $\mathrm{kg} \mathrm{ha}^{-1}$, corrected for standard moisture of $13 \%$. Corrected weight was obtained by the following equation: $C W=S Y$ plot $*\left[\frac{100-R M}{100-13}\right]$

, where $\mathrm{CW}$ is corrected weight; SYplot is a yield of each plot; RM is the real moisture of seeds at harvest and 13 the standard moisture content of $13 \%$. Real moisture was obtained by heating in an oven at $80^{\circ} \mathrm{C}$ until reaching constant weight, starting from initial moisture of $100 \mathrm{~g}$ of pure seeds. To calculate moisture content, expressed in moist weight, the following equation was used: $M \%=100 *\left[\frac{M W-D W}{M W}\right], \mathrm{M} \%$ is moisture content, MW is moist weight of seeds and DW is dry weight of seeds.

This study used a random block design in each cropping system. Cropping system and respective treatments per system were considered a fixed effect and the growing season random effect. Results were analyzed using the F-test and mean separation by Duncan's test to compare treatments within each cropping system and between systems. For comparisons between healthy and unhealthy plants or between growing seasons, the F-test was conclusive. Cropping systems and growing seasons were jointly analyzed as environmental effects. Pearson's correlation coefficient was applied as follows: (i) general correlation was performed for each growing season and (ii) specific correlation for each cropping system, in each soybean growing season. These correlations were based on seed yield (SY) correlated with root rot (RR) incidence. A 5\% significance level was set for all analyses. Statistical analysis was carried out using SAS software, version 9.2.

\section{RESULTS AND DISCUSSION}

Seed yield (SY) showed a significant difference from one growing season to another, between cropping systems and between treatments (Table 1). In the first growing season, in the soybean + oat cropping system, SY was significantly higher in treatments T1, T2 and T3, with 1942, 1916 and $2008 \mathrm{~kg} \mathrm{ha}^{-1}$ respectively, when compared to plants with symptoms of late RR (T4), where SY was only $1850 \mathrm{~kg} \mathrm{ha}^{-1}$ (Table 1). In the second season, plants with both early and late RR symptoms (T2, 2463 and T4, 2235kg ha ${ }^{-1}$ ) exhibited significant declines in relation to symptom-free plants (T1, 2633 and T3, $\left.2761 \mathrm{~kg} \mathrm{ha}^{-1}\right)$, respectively $(\mathrm{P}<0.05$; Table 1$)$.
In the soybean + maize cropping system, plants with early or late symptoms of RR (T2, 1906 or $\left.\mathrm{T} 4,1862 \mathrm{~kg} \mathrm{ha}^{-1}\right)$ were less productive than their symptom-free counterparts (T1, 2105 and T3, 2148kg $\mathrm{ha}^{-1} ; \mathrm{P}<0.05$; Table 1) and in the second season, T1, T2 and T3 produced 2300; 2265 and $2491 \mathrm{~kg} \mathrm{ha}^{-1}$, respectively, with significantly higher SY than that obtained in plants with late RR symptoms (T4), which produced only $2075 \mathrm{~kg} \mathrm{ha}^{-1}(\mathrm{P}<0.05$; Table 1$)$.

The soybean+wheat cropping system with RR symptoms (early or late) showed significantly lower SY (T2, 2001 or T4, 1940kg ha-1) compared to plants with no RR symptoms (T1, 2117 and T3, $2178 \mathrm{~kg} \mathrm{ha}^{-1}$ ) and in the second season, behavior was statistically equal, but the yields in plants with RR symptoms were T2, 1365 and T4, $1347 \mathrm{~kg} \mathrm{ha}^{-1}$, and those free of symptoms (early or late) T1, 1417 and T3, 1435kg ha ${ }^{-1}(\mathrm{P}<0.05$; Table 1$)$.

In general, the soybean+pasture cropping system was less productive, and plants with early or late RR symptoms (T2, 1263 and T4, 1271 $\mathrm{kg} \mathrm{ha}^{-1}$ ) produced statistically less compared to those with no RR symptoms (T1, 1409 and T3, $1401 \mathrm{~kg} \mathrm{ha}^{-1}$ ). Behavior differed in the second season, with yields of T1, 1500; T2, 1448 and T3, 1607 $\mathrm{kg} \mathrm{ha}^{-1}$, higher than those of T4 (late symptoms of RR) with only $1343 \mathrm{~kg} \mathrm{ha}^{-1}(\mathrm{P}<0.05$; Table 1). In summary, the SY of plants with early or late symptoms of RR was significantly lower $(\mathrm{P}<0.05)$ compared to plants with no RR symptoms, in both seasons and cropping systems (Table 1).

Considering the effect of cropping system in the first season, the soybean+oat, soybean+maize and soybean + wheat systems were more productive than the soybean+pasture system $(1929,2005$ and $2059 \mathrm{~kg} \mathrm{ha}^{-1}$, versus $1336 \mathrm{~kg} \mathrm{ha}^{-1}$; Table 1). In the second season, the most productive cropping system was soybean+oat $\left(2458 \mathrm{~kg} \mathrm{ha}^{-1}\right)$, followed by soybean+maize $\left(2283 \mathrm{~kg} \mathrm{ha}^{-1}\right)$, while soybean+wheat and soybean+pasture were once again the lowest productive, with 1391 and $1475 \mathrm{~kg} \mathrm{ha}^{-1}$, respectively $(\mathrm{P}<0.05$; Table 1$)$.

Considering only plants with and without late RR symptoms (T3xT4), seed yields increased significantly when only healthy plants were assessed in the soybean+oat, soybean+maize and soybean+wheat systems, obtaining SY of 2008, 2148 and $2178 \mathrm{~kg} \mathrm{ha}^{-1}$, respectively, while the soybean+pasture system produced only $1401 \mathrm{~kg} \mathrm{ha}^{-1}$ $(\mathrm{P}<0.05$; Table 1). In unhealthy plants, SY were 1850,1862 and $1940 \mathrm{~kg} \mathrm{ha}^{-1}$ in the soybean+oat, soybean+maize and soybean+wheat systems and once again the soybean+pasture system exhibited the lowest SY, with only $1271 \mathrm{~kg} \mathrm{ha}^{-1}(\mathrm{P}<0.05$; Table 1$)$. 
Table 1 - Soybean seed yield as a function of different cropping systems, root rot and growing seasons in Ponte Serrada, Santa Catarina (SC), Brazil.

\begin{tabular}{|c|c|c|c|c|}
\hline Systems & Treat & $2014 / 2015$ & $2015 / 2016$ & \\
\hline \multirow{2}{*}{ Soybean+oat } & -------. & -------------. & ---------------. & -------------. \\
\hline & $\mathrm{T} 1$ & b $1942 \mathrm{~A}^{/ 1}$ & 2/a $2633 \mathrm{~A}$ & \\
\hline \multirow{3}{*}{ Soybean+oat } & $\mathrm{T} 2$ & b 1916 A & a $2463 \mathrm{~B}$ & \\
\hline & T3 & b $2008 \mathrm{~A}$ & a $2761 \mathrm{~A}$ & \\
\hline & $\mathrm{T} 4$ & b $1850 \mathrm{~B}$ & a $2335 \mathrm{C}$ & \\
\hline \multirow[t]{4}{*}{ Soybean + maize } & $\mathrm{T} 1$ & a $2105 \mathrm{~A}$ & a $2300 \mathrm{~A}$ & \\
\hline & $\mathrm{T} 2$ & b 1906 B & a $2265 \mathrm{~A}$ & \\
\hline & $\mathrm{T} 3$ & b $2148 \mathrm{~A}$ & a $2491 \mathrm{~A}$ & \\
\hline & $\mathrm{T} 4$ & b $1862 \mathrm{~B}$ & b 2075 B & \\
\hline \multirow[t]{4}{*}{ Soybean+wheat } & $\mathrm{T} 1$ & a $2117 \mathrm{~A}$ & b 1417 A & \\
\hline & $\mathrm{T} 2$ & a $2001 \mathrm{~B}$ & b $1365 \mathrm{~B}$ & \\
\hline & $\mathrm{T} 3$ & a $2178 \mathrm{~A}$ & b $1435 \mathrm{~A}$ & \\
\hline & $\mathrm{T} 4$ & a $1940 \mathrm{~B}$ & b $1347 \mathrm{~B}$ & \\
\hline \multirow[t]{4}{*}{ Soybean + pasture } & $\mathrm{T} 1$ & a $1409 \mathrm{~A}$ & a $1500 \mathrm{~A}$ & \\
\hline & $\mathrm{T} 2$ & a $1263 \mathrm{~B}$ & b $1448 \mathrm{~A}$ & \\
\hline & $\mathrm{T} 3$ & b $1401 \mathrm{~A}$ & a $1607 \mathrm{~A}$ & \\
\hline & $\mathrm{T} 4$ & a $1271 \mathrm{~B}$ & a 1343 B & \\
\hline \multicolumn{5}{|c|}{ 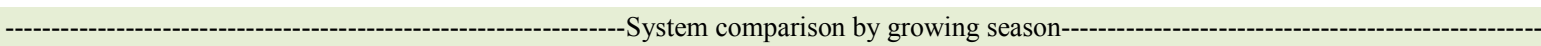 } \\
\hline & & $2014 / 2015$ & $2015 / 2016$ & \\
\hline Soybean+oat & & b 1929 A & a $2548 \mathrm{~A}$ & \\
\hline Soybean + maize & & b $2005 \mathrm{~A}$ & a $2283 \mathrm{~B}$ & \\
\hline Soybean+wheat & & a $2059 \mathrm{~A}$ & b $1391 \mathrm{C}$ & \\
\hline Soybean+pasture & & b $1336 \mathrm{~B}$ & a $1475 \mathrm{C}$ & \\
\hline \multicolumn{5}{|c|}{ 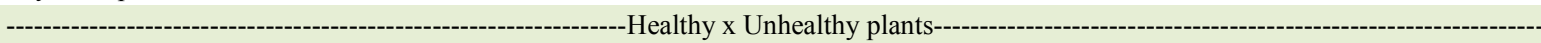 } \\
\hline & & Healthy & Unhealthy & $\neq \mathrm{kg} \mathrm{ha}^{-1}$ \\
\hline \multicolumn{5}{|c|}{ 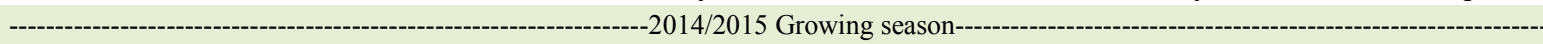 } \\
\hline \multicolumn{2}{|c|}{ Soybean+oat } & a $2008 \mathrm{~A}$ & a $1850 \mathrm{~A}$ & 158 \\
\hline \multicolumn{2}{|l|}{ Soybean+maize } & a $2148 \mathrm{~A}$ & b $1862 \mathrm{~A}$ & 286 \\
\hline \multicolumn{2}{|l|}{ Soybean+wheat } & a $2178 \mathrm{~A}$ & b $1940 \mathrm{~A}$ & 238 \\
\hline \multicolumn{2}{|c|}{ Soybean+pasture } & a $1401 \mathrm{~B}$ & a $1271 \mathrm{~B}$ & 130 \\
\hline \multicolumn{5}{|c|}{ 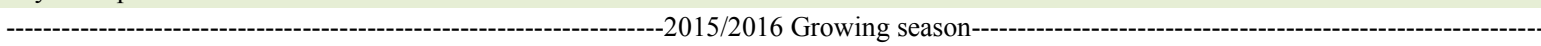 } \\
\hline \multicolumn{2}{|c|}{ Soybean+oat } & a $2761 \mathrm{~A}$ & b 2335 A & 426 \\
\hline \multicolumn{2}{|l|}{ Soybean+maize } & a $2491 \mathrm{~A}$ & b $2075 \mathrm{~A}$ & 416 \\
\hline \multicolumn{2}{|l|}{ Soybean + wheat } & a $1435 \mathrm{~B}$ & b $1347 \mathrm{~B}$ & 88 \\
\hline \multicolumn{2}{|l|}{ Soybean+pasture } & a $1607 \mathrm{~B}$ & b $1343 \mathrm{~B}$ & 264 \\
\hline \multicolumn{2}{|l|}{$\mathrm{CV} \%$} & 17.2 & 20.1 & \\
\hline
\end{tabular}

${ }^{/ 1}$ Means followed by the same upper case letter in the column do not differ according to Duncan's test, at $5 \%$ probability. ${ }^{/ 2}$ Means preceded by the same lower letter on the line (growing season comparison) do not differ according to the F-test at 5\% probability. Treat - treatments: $\mathrm{T} 1$ - plants with no early root rot symptom - RR (stage R2); T2 - plants with early RR symptoms; T3 - plants with no late RR symptoms (stage R8) and T4 - plants with late RR symptoms.

Differences in yields between healthy and unhealthy plants ranged from 130 to $286 \mathrm{~kg} \mathrm{ha}^{-1}$, equivalent to a difference of 2.2 to $4.8 \mathrm{bags} \mathrm{ha}^{-1}$ ( 1 bag corresponds to $60 \mathrm{~kg}$ ) in relation to $\mathrm{RR}$.

In the second season, T3xT4 confirmed that the highest yields are obtained from healthy plants. Seed yield differences between healthy and unhealthy plants ranged from 426, 416, 88 and $264 \mathrm{~kg} \mathrm{ha}^{-1}$, equivalent to $7.1,6.9,1.5$ and 4.4 bags ha $^{-1}$ respectively, for soybean+oat, soybean + maize, soybean+wheat and soybean+pasture cropping symptoms (Table 1).

The soybean main yield components are the number of plants per ha ${ }^{-1}$, number of pods per 
plant, number of seeds per pod and 1000 -seed weight (THOMAS \& COSTA, 2010). To achieve high yields, good crop management is necessary to obtain the maximum output of each component (THOMAS \& COSTA, 2010; SOUZA et al., 2013). However, in relation to RR, when plants are symptomatic they die, form dead patches or yellow leaves and later drooping branches, on which leaves wilt, dry out and stick to the stems, resulting in deformed seeds and pods (GUPTA et al., 2012; KLINGELFUSS et al., 2007). CRUCIOL \& COSTA (2017) evaluated two soybean cultivars artificially inoculated with RR dead patches and reported damage in $3.6 \%$ of the final production, representing losses of $2.2 \mathrm{bags} \mathrm{ha}^{-1}$. This damage was similar to that observed in our research, varying from 2.2 to 4.8 bags $\mathrm{ha}^{-1}$ in the first season and 1.5 to 7.1 bags $\mathrm{ha}^{-1}$ in the second (Table 1).

With respect to $R R$ incidence for the 2014/2015 season, a significant difference was reported between cropping systems, with the soybean+oat and soybean+maize systems obtaining lower RR incidence (Table 2). For the 2015/2016 season, the soybean+maize system exhibited the lowest RR values (about 20\% lower; Table 2). This result may be due to the effect of monoculture.

Predominance of RR by etiologic agent in the first season, irrespective of cropping system, showed 75\% Macrophomina and 25\% Fusarium (Table 2). In the second season, the incidence of Macrophomina was higher than that observed in the first season (96.9\%). Also, in the second season, particularly the soybean+oat system showed the lowest Fusarium predominance (3.1\%) than others (Table 2). Greater predominance of grey rot in the second season may be due to the lower rainfall observed between 130 and 150 days of the cycle (Figure 1B versus 1A) in addition to the fact that the fungus is a natural soil inhabitant. Another possibility is that the presence of soybean plant residues, particularly in the soil, increases propagation capacity via Macrophomina microsclerotia (REIS et al., 2014).

In Ponte Serrada, agricultural zoning indicates seeding time among Julian days from 290 to 360 , whose seeding dates are between October 11 and December 31 (BRASIL, 2016). However, farmers prefer to seeding from 300 to 320 Julian days, avoiding early and latter days, because the soybean crop at this time is less affected by disease compared to the end of the recommended period (days 330 to 360 ), when the amount of disease inoculum available may be higher and would potentially increase the incidence and predominance of diseases such as RR.

The overall average of all the systems showed a decline of 23.0 and $22.6 \mathrm{~kg} \mathrm{ha}^{-1}$ in SY per $1 \%$

Table 2 - Incidence and predominance of root rot in soybean plants as a function of different cropping systems in two growing seasons in Ponte Serrada, SC

\begin{tabular}{|c|c|c|c|c|}
\hline \multirow[t]{2}{*}{ Cropping systems } & \multicolumn{2}{|c|}{ 2014/2015 Growing season } & \multicolumn{2}{|c|}{ 2015/2016 Growing season } \\
\hline & \multicolumn{4}{|c|}{------------------------------------------------------------------ $\%$------------------------------------------------------------ } \\
\hline Soybean+oat & \multicolumn{2}{|c|}{ a $60.0 \mathrm{~B}^{/ 1}$} & \multicolumn{2}{|c|}{${ }^{2 /} \mathrm{a} 54.7 \mathrm{~A}$} \\
\hline Soybean + maize & \multicolumn{2}{|c|}{ a $50.4 \mathrm{~B}$} & \multicolumn{2}{|c|}{ a $46.1 \mathrm{~B}$} \\
\hline Soybean+wheat & \multicolumn{2}{|c|}{ a $72.5 \mathrm{~A}$} & \multicolumn{2}{|c|}{ b $52.0 \mathrm{~A}$} \\
\hline Soybean+pasture & \multicolumn{2}{|c|}{ a $74.9 \mathrm{~A}$} & \multicolumn{2}{|c|}{ b $58.7 \mathrm{~A}$} \\
\hline \multirow[t]{5}{*}{$\mathrm{CV} \%$} & \multicolumn{2}{|c|}{13.5} & \multicolumn{2}{|c|}{28.4} \\
\hline & \multicolumn{4}{|c|}{ 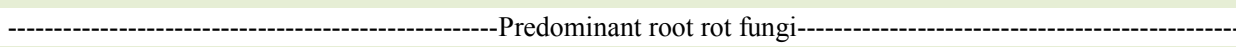 } \\
\hline & \multicolumn{4}{|c|}{ 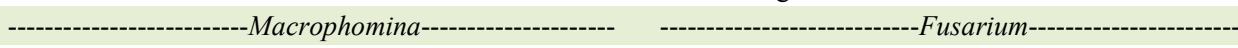 } \\
\hline & \multicolumn{2}{|c|}{$2014 / 2015$ Season 2015/2016 Season } & 2014/2015 Season & 2015/2016 Season \\
\hline & \multicolumn{4}{|c|}{ 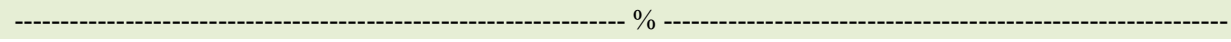 } \\
\hline Soybean+oat & b $71.5 \mathrm{~ns}$ & a $96.9 \mathrm{~A}$ & a $28.5 \mathrm{~ns}$ & b $3.1 \mathrm{~B}$ \\
\hline Soybean + maize & b 73.7 & a $88.8 \mathrm{AB}$ & a 26.3 & b $11.2 \mathrm{~A}$ \\
\hline Soybean+wheat & b 79.0 & a $88.9 \mathrm{AB}$ & a 21.0 & b $11.1 \mathrm{~A}$ \\
\hline Soybean+pasture & b 75.8 & a 81.7 B & a 24.2 & b $18.4 \mathrm{~A}$ \\
\hline Mean & 3/a 75.0 & & b 25.0 & \\
\hline $\mathrm{CV} \%$ & 9.5 & 8.4 & 28.6 & 7.11 \\
\hline
\end{tabular}

${ }^{/ 1}$ Means followed by the same upper case letter in the column (system comparison) do not differ according to Duncan's test, at $5 \%$ probability. ${ }^{12}$ Means preceded by the same lower letter on the line (growing season comparison) do not differ according to the F-test at $5 \%$ probability. ${ }^{3 /}$ Differ according to the F-test at $5 \%$ probability. 
increase in RR incidence in the first and second seasons, respectively (Figure 2A and C). Individual analysis of cropping system demonstrated a decrease in SY of $20.9 ; 20.6 ; 102.9$ and $74.9 \mathrm{~kg} \mathrm{ha}^{-1}$ per $1 \%$ increase in RR for soybean + oat, soybean + maize, soybean + wheat and soybean+pasture systems, respectively (Figure 2B). In the 2015/2016 season, SY fell by 26.3, 32.9, 9.2 and $19.8 \mathrm{~kg} \mathrm{ha}^{-1}$ per $1 \%$ increase in $\mathrm{RR}$, for soybean+oat, soybean + maize, soybean+wheat and soybean+pasture systems, respectively (Figure 2D). A comparison of all the systems with RR showed that yield declined with the increase in diseases, regardless of season, cropping system and the presence of dead patches in soybean crops (Figure 2). The soybean+oat and soybean+maize cropping systems were consistently more productive in healthy than unhealthy plants, with differences of more than 158 and $286 \mathrm{~kg} \mathrm{ha}^{-1}$ in the first season and 426 and $416 \mathrm{~kg} \mathrm{ha}^{-1}$ in the second season, respectively (Table 1). Results reported by REIS et al. (2014) demonstrated that soybean grown after maize was more productive than a soybean monoculture grown after winter grasses. These authors also reported more Macrophomina than Fusarium in soybean plant roots. JULIO et al. (2016) obtained higher soybean yield in a millet-soybean succession system than fallow-soybean, maintaining healthy plants to harvesting maturity stage.

\section{CONCLUSION}

In the 2014/2015 and 2015/2016 growing seasons, grey rot predominated in relation to sudden death syndrome. Incidence of RR, regardless of crop, early or late RR symptoms and cropping system was more than $50 \%$, resulting in losses of $22 \mathrm{~kg} \mathrm{ha}^{-1}$ of seeds per $1 \%$ increase in RR, or between 1.5 and 7.1 bags ha- ${ }^{-1}$ of soybean seeds. The soybean+oat and soybean+maize cropping systems were consistently more productive than their soybean+wheat and soybean+pasture counterparts.

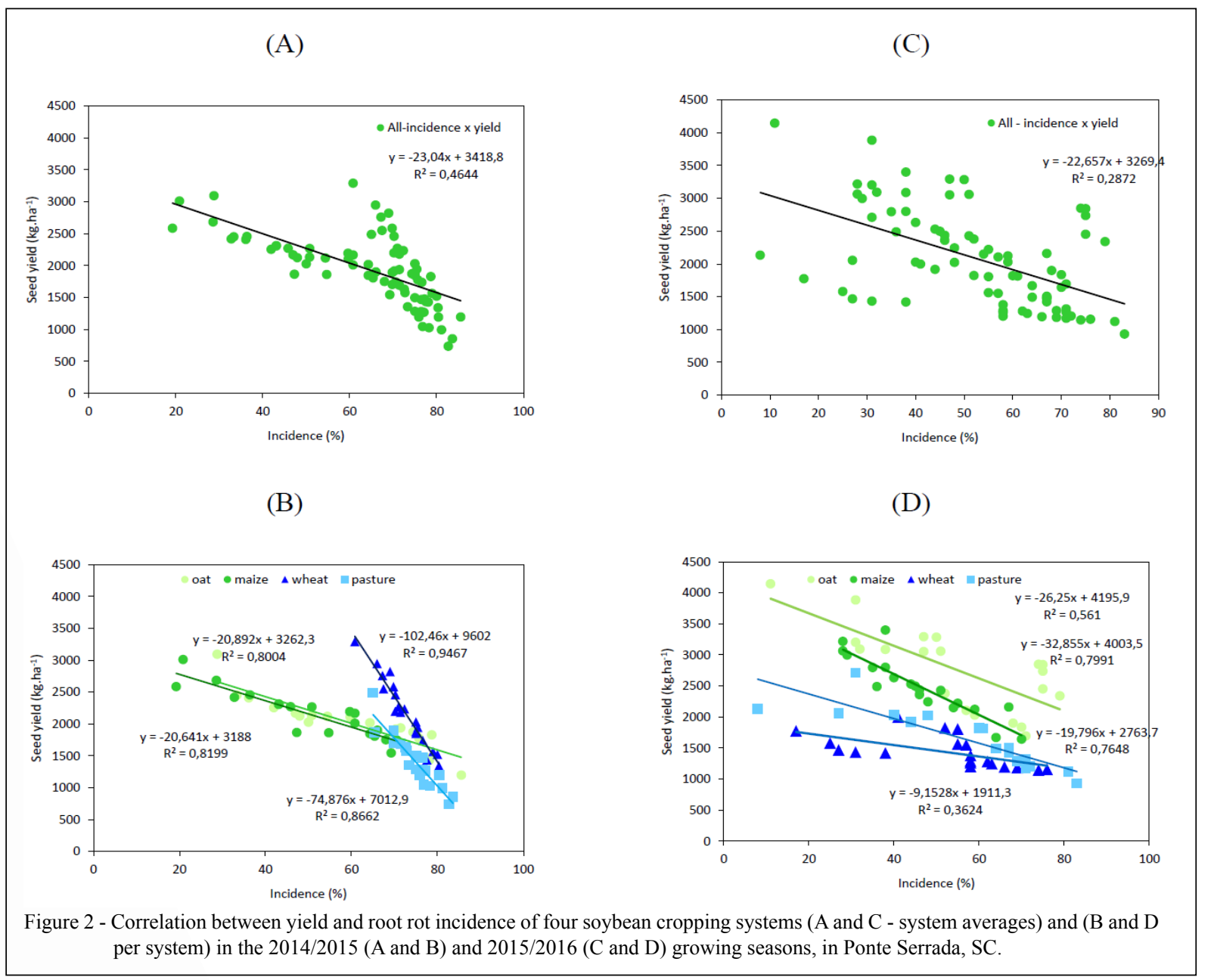

Ciência Rural, v.48, n.7, 2018. 


\section{ACKNOWLEDGEMENTS}

The authors thank the Conselho Nacional de Desenvolvimento Científico e Tecnológico (CNPq/Universal 460983/2014-8); Coordenação de Aperfeiçoamento de Pessoal de Nível Superior/Programa de Apoio à Pós-graduação (CAPES/ PROAP) and Fundação de Amparo a Pesquisa e Inovação do Estado de Santa Catarina (FAPESC/PAP/UDESC) research funding agencies for financial support. To Conselho Nacional de Desenvolvimento Científico e Tecnológico (CNPq) Research Productivity Scholarship, Brazil, for the Souza, C.A. and to Casa, R.C. and, FAPESC/Promop for the study grants awarded for Maier, $\mathrm{M}$.

\section{CONFLICTS OF INTEREST}

The authors declared no potential conflicts of interest with respect to the research, authorship, and/or publication of this article.

\section{REFERENCES}

ABRASEM - Associação Brasileira de Sementes e Mudas. Estatísticas, soja, safra 2015. Available from: <http://www.abrasem.com.br/site/ estatisticas/\#>. Accessed: Apr. 13, 2018.

BRASIL, Ministério da Agricultura, Pecuária e Abastecimento (MAPA), Gabinete do Ministro. Portaria n. 180, Brasília, 2016. DOU de 22/08/2016, n. 198, Seção 1, p. 4.

CONAB. Perspectivas para a agropecuária, safra 2017/2018, produtos de verão. Perspectivas para a Agropecuária, v.5, p.95-108, 2017a. Available from: <https://www.conab.gov.br/OlalaCMS/uploads/ arquivos/17_09_06_09_30_08_perspectivas_da_agropecuaria_ bx.pdf>. Accessed: Apr. $\overline{13}, 2 \overline{0} 18$.

CONAB. Acompanhamento da safra brasileira de grãos, safra 2017/18, terceiro levantamento, dezembro 2017. Acompanhamento da Safra Brasileira de Grãos, v.5, p.1-130, 2017b. Available from: <https:// www.conab.gov.br/OlalaCMS/uploads/.../17_12_12_09_15_51_ dezembro.pdf $>$. Accessed: Apr. 13, 2018.

COSTAMILAN, L.M. et al. Sobrevivência de fungos necrotróficos em restos de cultura de soja, em sistema de plantio direto. Fitopatologia Brasileira, v.24, p.175-177, 1999.

CRUCIOL, G.C.D.; COSTA, M.L.N. Influence of Macrophomina phaseolina inoculation methodologies on the performance of soybean cultivars. Summa phytopathologica, v.43, p. 337-343, 2017. Available from: $<$ http://dx.doi.org/10.1590/0100-5405/2185>. Accessed: Apr. 23, 2018.

FREITAS, M.M. The soybean crop in Brazil: the increase of the brazilian production and the emergence of a new agricultural frontier.
Enciclopédia Biosfera, Centro Científico Conhecer, v.7, p.112, 2011. Available from: <www.conhecer.org.br/enciclop/2011a/ agrarias/a\%20cultura\%20da\%20soja.pdf $>$. Accessed: Apr. 13, 2018.

GUPTA, G.K. et al. Biology, epidemiolgy and management of the pathogenic fungus Macrophomina phaseolina (Tassi) Goid with special reference to charcoal rot of soybean (Glycine max (L.) Merrill). Journal of Phytopathology, v.160, p.167-180, 2012. Available from: $<$ https://doi.org/10.1111/j.1439-0434.2012.01884.x>. Accessed: Apr. $13,2018$.

HENNING, A.A. Manejo de doenças da soja (Glycine max L. Merrill). Informativo Abrates, v.19, p.9-12, 2009. Available from: $<$ http://www. abrates.org.br/informativo-abrates/edicao>. Accessed: Apr. 13, 2018.

JULIO, O.L.L. et al. Methods of potassium fertilization and yield in soybean crop. Revista Agrarian, v.9, p.149-155, 2016. Available from: <http://dx.doi.org/10.30612/agrarian.v9i32.4004>. Accessed: Apr. 13, 2018.

KLINGELFUSS, L.H. et al. Inoculation methods for identification of resistance in soybean to Fusarium solani f. sp. glycines under greenhouse conditions. Fitopatologia Brasileira, v.32, p.50-55, 2007. Available from: $<$ http://dx.doi.org/10.1590/S0100-41582007000100007>. Accessed: Apr. 13,2018 .

PEREZ-BRANDAN, C. et al. Soybean fungal soil-borne diseases: a parameter for measuring the effect of agricultural intensification on soil health. Canadian Journal of Microbiology, v.60, p.73-84, 2014. Available from: <http://dx.doi.org/10.1139/cjm-2013-0792>. Accessed: Apr. 13, 2018.

REIS, E.M. et al. Effects of crop rotation on root rot incidence and on soybean grain yield. Summa Phytopathologica, v.40, p.9-15, 2014. Available from: <http://dx.doi.org/10.1590/S010054052014000100001>. Accessed: Apr. 13, 2018.

SARR, M.P. et al. Genetic diversity in Macrophomina phaseolina, the causal agent of charcoal rot. Phytopathologia Mediterranea, v.53,p.250-268, 2014. Available from: $<$ http://dx.doi.org/10.14601/ Phytopathol Mediterr-13736>. Accessed: Apr. 13, 2018.

SHADAKSHARI, T.V. et al. Morphological response of soybean under water stress during pod development stage. Legume Research - An International Journal, v.37, p.37-46, 2014. Available from: <http:// dx.doi.org/10.5958/j.0976-0571.37.1.006>. Accessed: Apr. 13, 2018.

SOUZA, C.A. et al. Plant architecture and productivity of soybean affected by plant growth retardants. Bioscience Journal, v.29, p.634-643, 2013. Available from: <http://www.seer.ufu.br/index.php/ biosciencejournal/article/view/14181>. Accessed: Apr. 13, 2018.

THOMAS, A.L.; COSTA, J.A. Soja: manejo para alta produtividade de grãos. Porto Alegre-RS: Editora Evangraf, 2010. 248p. 